\title{
DOMESTIC VIOLENCE AGAINST WOMEN FROM THE PERSPECTIVE OF THE COMMUNITY HEALTH AGENT
}

\author{
Rosa Maria Godoy Serpa da Fonseca ${ }^{1}$ \\ Ana Emilia Ramos Bagueira Leal ${ }^{2}$ \\ Thais Skubs ${ }^{2}$ \\ Rebeca Nunes Guedes ${ }^{3}$ \\ Emiko Yoshikawa Egry ${ }^{4}$
}

Fonseca RMGS, Leal AERB, Skubs T, Guedes RN, Egry EY. Domestic violence against women from the perspective of the community health agent. Rev Latino-am Enfermagem 2009 novembro-dezembro; 17(6):974-80.

This study addresses violence against women from the perspective of Community Health Agents and related care practices developed at the basic care level. It aims to understand their opinions and care practices in daily care delivery in order to support training of workers on this theme. The theoretical-methodological reference was gender violence as a social construct and ideology as a social product and guider of health care practices. Data collection was carried out through a questionnaire with closed questions addressing these professionals' positions in relation to facts in the care delivery context. The results showed that positions and conceptions are mostly supported by common perceptions, that is, they do not differ from women victims of violence or lay people in general, which leads to the conclusion that it is necessary to broaden the discussion of this problem, introducing the gender perspective in the acknowledgement and care of women.

DESCRIPTORS: family health; violence against women; gender and health

\section{VIOLENCIA DOMÉSTICA CONTRA LA MUJER EN LA VISIÓN DEL AGENTE COMUNITARIO DE SALUD}

Se trata de una investigación sobre la visión del agente comunitario de salud acerca de la violencia contra la mujer y las prácticas de los cuidados correspondientes, desarrollados en el sector de la atención básica de salud. Tuvo como objetivo comprender el posición y las prácticas de los cuidados en lo cotidiano del trabajo en salud, para subsidiar procesos de calificación del trabajador al respecto del tema. El marco teórico metodológico fue la violencia de género como constructo social y la ideología como producto social y orientador de las prácticas de salud. La recolección de datos fue realizada mediante aplicación de cuestionario con preguntas cerradas, acerca de la posición delante de hechos de la realidad asistencial. Los resultados mostraron posiciones y concepciones mayoritariamente apoyadas en el sentido común, o sea, no eran diferentes, en nada, de las que tenían las mujeres víctimas de violencia o de las opiniones de los legos en general, llevando a la conclusión de que es necesario ampliar el espacio de discusión del problema, propiciando la introducción de la perspectiva de género en el reconocimiento y en la atención a las mujeres.

DESCRIPTORES: salud de la familia; violencia contra la mujer; género y salud

\section{VIOLÊNCIA DOMÉSTICA CONTRA A MULHER NA VISÃO DO AGENTE COMUNITÁRIO DE SAÚDE}

Trata-se de pesquisa sobre a visão do agente comunitário de saúde acerca da violência contra a mulher e as práticas cuidativas correspondentes, desenvolvidas no nível da atenção básica de saúde. Teve como objetivo compreender o posicionamento e as práticas cuidativas no cotidiano do trabalho em saúde, para subsidiar processos de qualificação do trabalhador a respeito do tema. O referencial teórico-metodológico foi a violência de gênero como construto social e a ideologia como produto social e norteador das práticas de saúde. A coleta de dados foi realizada mediante aplicação de questionário com perguntas fechadas, acerca do posicionamento diante de fatos da realidade assistencial. Os resultados mostraram posições e concepções majoritariamente apoiadas no senso comum, ou seja, nada diferindo das mulheres vítimas de violência ou leigos em geral, levando à conclusão de que é necessário ampliar o espaço de discussão do problema, propiciando a introdução da perspectiva de gênero no reconhecimento e no atendimento às mulheres.

DESCRITORES: saúde da família; violência contra a mulher; gênero e saúde

Escola de Enfermagem, Universidade de São Paulo, Brasil: ${ }^{1}$ Full Professor, e-mail: rmgsfon@usp.br. ${ }^{2}$ RN, Specialist in Public Health, e-mail: ae.leal@uol.com.br, thaisskubs@gmail.com. ${ }^{3} \mathrm{RN}$, Doctoral Student, Programa Interunidades de Doutoramento em Enfermagem da Escola de Enfermagem e Escola de Enfermagem de Ribeirão Preto, Universidade de São Paulo, Brazil, e-mail: rebecanunesguedes@usp.br. ${ }^{4}$ Professora Titular, e-mail: emiyegry@usp.br. 


\section{INTRODUCTION}

Domestic violence against women has acquired social visibility and become the theme of several studies and world conferences in the last twenty years. "The identification of occurrences of abuse and violations against women in the framework of a larger reference of 'gender relations' permitted understanding the context in which these behaviors take place, revealing a scenario of inequities and domination that permeates private and public lives and power relations between men and women in society ${ }^{(1) \prime \prime}$

Although the relation of gender domination and oppression has been present since the beginnings of humanity, it only became significant and acquired the outline of a scientific issue and important focus of actions of public health beginning in the 1970s. In Brazil, recognition occurred simultaneously with claims of organized social movements, including those linked to access to public health services and the improvement of quality of life, especially in urban centers $^{(2)}$

The current concept of domestic violence against women includes all acts of physical, emotional, sexual violence and disregard for women's rights in terms of reproduction or legal rights and oppression, perpetrated by a family member or someone who lives or have lived in the same house ${ }^{(3)}$. "Gender violence is a world problem linked to power, privilege and male control. It affects women regardless of age, color, ethnicity, religion, nationality, sexual orientation or social status. The effect is mainly social, because it affects well-being, safety, women's chances of education and personal development and self-esteem. Historically, domestic and sexual violence are coupled with other forms of violations of women's rights $[\ldots]^{\prime \prime(4)}$.

Gender violence has received increased attention and mobilization in the last three decades. The initial statistical data point to spouses and family members as the main aggressors. In a study carried out in the Health District of Butantã in São Paulo, Brazil, 44.4\% of women between 15 and 49 years of age reported they had already suffered at least one event of gender-based physical violence in their lives $^{(5)}$.
Based on the magnitude and visibility of violence against women, violence is a public health problem and a phenomenon that is characterized by human rights violations. Laws to protect women's rights have been established at the international level and bodies and forums in their defense were concomitantly created or strengthened, which enabled, for the first time, the possibility to plan and put into practice public policies necessary for delivering care to women victims of gender violence. These initiatives, such as the creation of police departments dedicated specifically to women more than a decade ago, have changed the situation in Brazil.

Another milestone in the fight against gender violence is the creation of the law $11.340 / 2006$, also called Maria da Penha law. Generally speaking, it requires increased rigor in punishing aggression against women perpetrated in the domestic environment: it allows offenders who are caught in the act to be taken into custody immediately in addition to the enforcement of more severe penalties and other protective measures. This new law also establishes guidelines so the State, in its diverse spheres of action, organizes itself so as to change the previous scenario of suffering, disease and inequality ${ }^{(6)}$.

Although gender violence in the family environment is acknowledged as a public health problem, since it affects women of all social classes, many times the victims do not know their rights or even which laws support them. They frequently believe that being subject to physical or psychological abuse originates in their own behavior, or even that their aggressors, in the case of their spouses, have the right to be aggressive ${ }^{(3)}$.

The problem frequently reflects on these women's health and consequently affects their quality of life. Marital violence and rape have been associated with the highest levels of suicide, drugs and alcohol abuse, vague physical complaints, headaches, gastrointestinal and emotional disorders in general. In relation to reproductive life, violence against women has been associated with chronic pelvic pain, sexually transmitted diseases (STD) such as Acquired Immunodeficiency Syndrome (AIDS) in addition to inflammatory pelvic diseases and unwanted pregnancies $^{(4)}$. 
Additionally, when women who endure abusive relationships have their individual health (physical and mental) significantly compromised, their families' health and lives are compromised as a whole, thus a larger dimension is affected ${ }^{(7)}$.

Coupled with these, sociability and personal self-realization is diminished, affecting professional development and productive capacity ${ }^{(5)}$. "Considering the participation of women in decision-making processes, their incorporation in the structures of power is incipient, slow, and very limited. Therefore, what is evidenced is the persistence of cultural boundaries that hinder women to acquire abilities to exercise power, low effective participation of women in structures of power (less than $5 \%$ of the parliamentary government are women) and in political parties and there is even a setback in terms of mobilization in favor of typically feminist flags" (8).

Given this scenario, it is important to contextualize the view of gender in the proposals of the Unique Health System (SUS) and seek to overcome hegemonic social values that naturalize inequalities and justify oppression and violence against women. This ideology is entrenched in professional education and allows this view to be multiplied in health practices.

With the implementation of Community Health Agents Program (CHAP) in 1991 and afterwards with the creation of the Family Health Program (FHP) in 1994, the teams frequently face situations difficult to manage when these are related to man/woman relationships. This study focuses on the specific perspective and opinion of the community agent in relation to this issue. This professional category was chosen because its position in cases of violence is strategic since the involved actors (clients and professionals) belong to the same geo-social sphere ${ }^{(9)}$.

For care delivery to occur in the most appropriate way it is necessary to train health professionals through the inclusion of methodologies that privilege people's qualification under the perspective of gender issues. The existence of gender categories presupposes understanding of social relationships that are established between sexes, distinguishing between biological and social sexes, establishing inequalities between sexes as a historically determined social construct.
It is important to stress that individual and collective actions that aim to protect and promote health and educational activities are included in the functions of community agents. They have to give priority to more vulnerable groups and act as agents of change in the collective ${ }^{(10)}$.

The Family Health Program is a strategy that can ease the process of identification of cases of violence in the community due to the proximity of health professionals to their clientele in areas covered by the program. Thus, it is possible to act with social groups and strengthen their resources so as to cope with this kind of difficulty.

The Family Health Program is composed of one physician, one nurse, two nursing auxiliaries and about four to six community health agents, who are usually women. These are the actors involved in the process of identification of and intervention in cases of violence at the primary care level. However, greater visibility is given to the role of the Community Health Agent $(\mathrm{CHA})$ since this is the link between the health service and the community. Living in the same area as their clients, these professionals have the means to evaluate the families' dynamics and many times to identify situations of risk or actual violence by observation or through the bond they establish with the clientele. What occurs, most of the time, is that women end up reporting facts to the CHAs they would not report to other professionals, which enable these professionals to prevent or intervene in these situations ${ }^{(10)}$.

From this perspective, the understanding from the position of CHAs in relation to gender violence and related practices is pertinent and necessary, considering these professionals are part of the community to which they also deliver care, a fact that permits them to be closer to the objective reality of situations.

We understand that the identification and understanding of professional practices focused on women who experience situations of violence offer the possibility to define welfare policies concerning gender in regard to fighting violence against women. In addition, it supports the training of $\mathrm{CHAs}$ to acknowledge and intervene in situations of violence and contributes to a critical view of their own role inside the FHP as actors capable of intervening in the health/disease process of families. 
Thus, this study, through arguments based on empirical data, defines gender welfare policies to cope with violence against women. To fulfill this purpose, this study identifies and analyzes the position and professional practice of CHAs in relation to violence against women under the perspective of gender issues.

\section{METHOD}

The theoretical reference was based on the following analytical categories: gender violence as social construct and ideology as social product and guider of health practices.

The study was carried out in the Health District of Butantã located in the West area of São Paulo, SP, Brazil. Seventeen CHAs of a Basic Care Unit (BCU) that works with the Family Health Strategy, which puts SUS guidelines into practice and operation, participated in the study.

Data were collected through the application of a questionnaire composed of 30 thematic statements about $\mathrm{CHAs}^{\prime}$ positions in relation to violence against women. Based on their understanding of these statements, the participants should indicate whether they totally, partially or did not agree with the situations or assessments.

The questionnaire was based on reports of real situations of violence and practices that these situations required from community health agents of the FHP teams in a city in the interior of São Paulo, Brazil during another study inside the same project ${ }^{(11)}$, which was partially supported by the National Council for Scientific and Technological Development (CNPq).

The proposal is to collect situations such as people's stories that show the suffering reported by those who experience these situations and facilitate understanding why people do what they $\mathrm{do}^{(12)}$. These reports, with the same language used by the participants, were submitted to content analysis ${ }^{(13)}$, which seeks to understand the meaning of their statements in connection with the addressed issue, exposing the conflicts and contradictions that construct their narratives and resulted in thematic statements related to the following categories: anger of the male abuser; anger of the abused female, understanding and feeling sorry for the abused woman; feelings of powerlessness, relief, despair and resignation; willingness to help the woman; glimpsing idealized solutions. Subsequently, only those categories that more explicitly put forward the ideas from the reports were chosen and the questionnaire was developed.

Because human subjects were involved in the study, both studies followed all recommendations of Resolution n. 196 of October 1996 of the National Health Council ${ }^{(14)}$. Therefore, each community health agent who agreed to participate in the study signed two copies of a free and informed consent agreement where the study's theme and objectives were presented. They were ensured anonymity of provided information and also that it would be exclusively used for scientific purposes.

This study is a part of the larger research project "Professional practices and violence against women: from the perspective of gender and social class" approved by the Research Ethics Committee at the University of São Paulo, College of Nursing (EEUSP) Protocol n. 517/2005/CEP-EEUSP.

\section{RESULTS}

The population of this study was composed of 17 women aged between 22 and 50 years, minimum education was the $8^{\text {th }}$ degree of middle school, six worked in the same BHC since it was implemented, that is, six years ago and they were all residents in the unit's scope area.

Data analysis was carried out according to the categories previously mentioned and which revealed gender violence against women. The empirical categories were coded according to the following: disgust and anger against the aggressor (A), disgust and anger against the abused woman $(B)$, understanding and feeling sorry for the abused woman (C), sense of relief (I), helplessness (D), hopelessness and resignation (E). Three practices were chosen as experienced practices: listening and providing guidance without taking sides $(F)$, willingness to help the abused woman (G) and glimpsing idealized solutions $(\mathrm{H})$. 


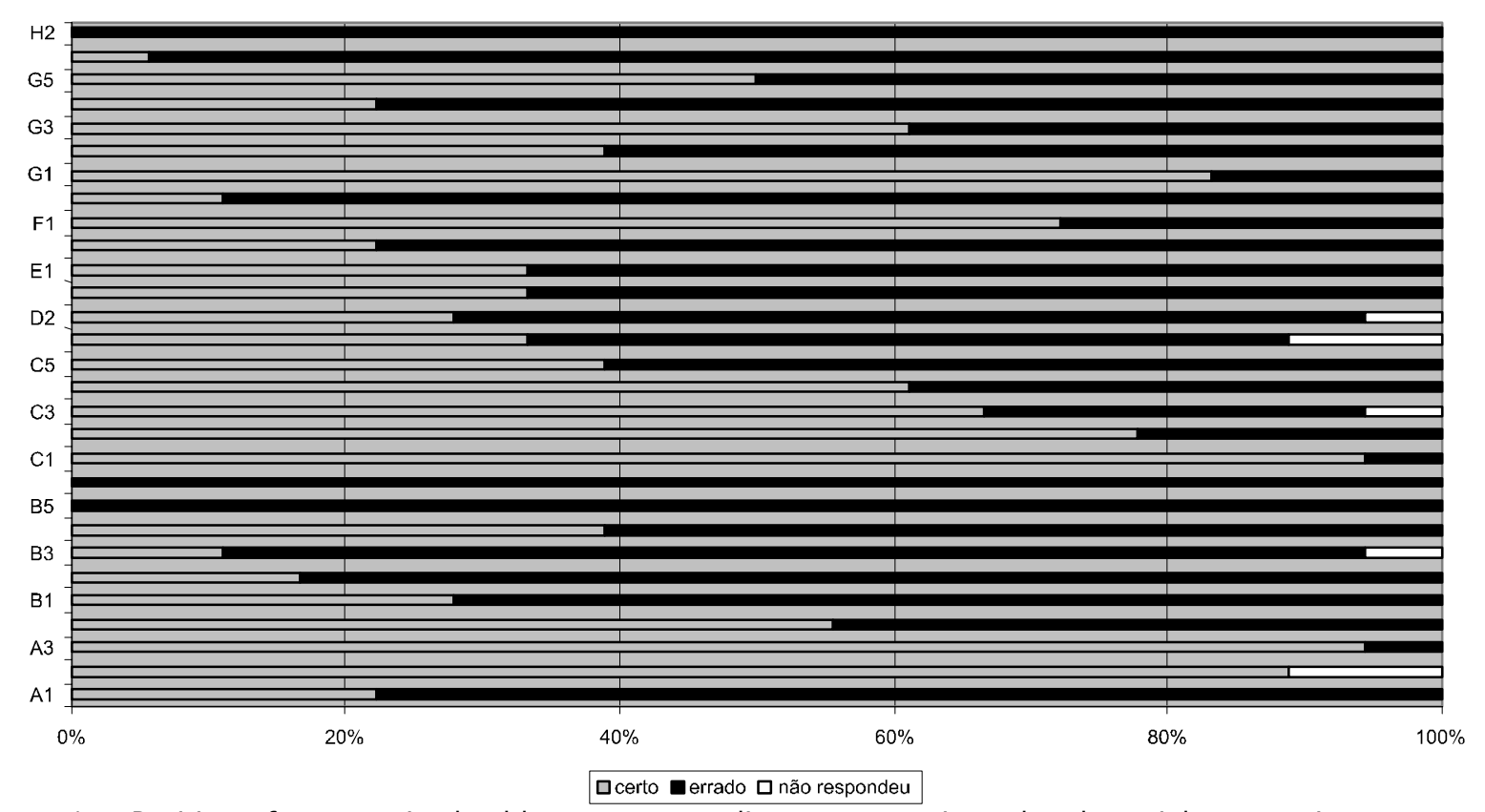

Figure 1 - Position of community health agents according to categories related to violence against women

\section{DISCUSSION}

Figure 1 shows that empirical category A disgust and anger against the aggressor - was the one that presented the majority of results appropriate to thematic statements that expressed this situation, with the exception of question $A 2$, which mostly presented an unfavorable position. These responses reflect common perceptions because they classify those involved into victims and aggressors, which disallows the possibility of reverting the violent event, since the woman is immobilized due to her condition and the man only pays for his wrongdoing, trying at the same time to reduce the cost. The offender is the aggressor and the offended is the victim; power is attributed only to the first.

Power is not something that can be shared among those who exclusively hold it and those who do not have it and are subject to it. In other words, power does not apply to individuals, but rather it goes through them and the individual is one of the first effects of power ${ }^{(15)}$.

Violence against women is a phenomenon rooted in gender inequalities, reflected in asymmetric power relations and, even if this power is relational, reality has shown that it hardly favors women, who are mostly the preferred target of gender violence.

The category B - disgust and anger towards the abused woman - mostly presented inappropriate results considering the gender perspective. It reflects the position that all women have the possibility and ability to stop violent relationships as if it depended only on them, disregarding all the difficulties related to the fact. Women are generally responsible for the maintenance of the house and family, functions that become increasingly more difficult when they are carried out alone, the more one moves down the social hierarchy in a combination of class and gender ${ }^{(16)}$. Additionally, the construction of the sociocultural female universe has for a long time legitimated the negative image of women's imperfectionn. Over the centuries, the idea that women are fragile, submissive and imperfect is engendered in the social imagery, which even today, reflects profound effects on the configuration of the field of health care and violence.

The category $\mathrm{C}$ - understanding and feeling sorry for the abused woman - presented a position that tends to be appropriate, probably a result of humanization in the field of nursing. It can be influenced by the way the actors involved in the care process construct their own gender identity and transfer their ideology to care delivery ${ }^{(17)}$.

Category D - helplessness - expressed inappropriate behavior in the face of the situation, corroborating what occurred with the other categories. Feelings such as helplessness or despair in the face of situations difficult to solve can immobilize the professional's action and usually is a consequence of lack of preparedness in relation to the apparatus the State provides to support offended women. 
The category E - hopelessness and conformism - reaffirmed previous results since inappropriate behavior predominated in the responses showing that CHAs lack appropriate perceptions concerning their own role as professionals. It also reflects an ideal situation, attributing a social order to roles constructed in the face of social relationships considered to have no conflicts or contradictions. Considering that health practices interfere with social phenomena so as to overcome or legitimate the status quo, we understand here that this category reproduces the naturalization of female oppression in the sphere of heath care, which can be translated into the omission of effective care, solidarity and protection in addition to hindering the exercise of professional practice as an instrument of social emancipation.

The categories that represent professional practice show that the way the phenomenon has been addressed, under the perspective of care, has not been translated into effective practices to overcome gender violence. From this perspective, the professional practices of the FHP focused on women in situations of violence should become practices that strengthen female autonomy, considering that the social construction of gender determines the destructive processes in women's lives.

The predominance of listening without taking sides $(F)$ reflects the myth that when professionals express their positions on a matter with their clientele, they have had unnecessary or even erroneous involvement, which is something that should be avoided at any cost. It can also mean a lack of professional preparedness in the face of complex situations, where one only knows how to deal with situations through listening. It reflects a view of care practice based on scientific neutrality and not on the professional's personal involvement, disregarding the political aspect of health practices. It is associated with the ways of organizing social systems that are based on patriarchy, whose power and control tactics are incorporated into the logic of society and therefore belongs to the base of science and has to be overcome to achieve a fair and egalitarian society ${ }^{(18)}$.

Category $(G)$ - willingness to help the abused woman - expresses a division of tendencies for analogous positions in several sentences of the questionnaire, which can denote indecision about ways to intervene. It reflects the notion of the social compromise of health practices, still partially employed, destined for women. In the case of female professionals, it can also reveal empathy and involvement.

Finally, the last category - glimpsing idealized solutions $(\mathrm{H})$ - almost all its responses are inappropriate from the perspective of gender. It disregards the complexity of social construction in determining violence against women, revealing a view of the world in which the cause of phenomena is located only in a singular dimension, disregarding the concrete structure of the society that guides social phenomena.

\section{CONCLUSIONS}

This study revealed a perspective based on the ideology of male domination in relation to gender violence and also showed the profound contradictions existent in the core of care practice to which it is related. The professionals' lack of preparedness in the face of violence against women became evident, indicating that investments are needed to enable professionals to feel capable of creating strategies of identification and intervention within the collective, jointly with the Family Health Care Team.

The CHAs are certainly the professionals who are the closest to the clientele in the area and therefore have access to essential information about these individuals, enabling greater proximity to everything that surrounds violence against women.

Research from the last ten years in the LatinAmerican Journal of Nursing ${ }^{(7,19-22)}$ confirms the magnitude of the importance of this theme to women's health since it confirms gender violence as a destructive phenomenon in the women's health/ disease process. Violence in the reported studies is presented as a multifactored phenomenon having important intersections with other determinants of women's health such as the use of drugs, low selfesteem and ways of living and working. Corroborating the intrinsic relationship between violence and health addressed in this periodical, this study contributes to knowledge about the theme with a view to demonstrate that, violence being a matter of health, investigating how the professionals involved with women's care understand and deal with the phenomenon is needed.

In this way, this study is expected to support the qualification of $\mathrm{CHAs}$ and other professionals for actions focused on gender issues, related to violence 
against women, strengthening SUS basic guidelines such as access, equity and integrality, which considers the individual as a whole when delivering care. In the future we intend to broaden the view of what it means to cope with violence against women in the sphere of the FHP.

\section{REFERENCES}

1. Prefeitura do Município de São Paulo. Mulheres em São Paulo: um perfil da cidade. Coordenadoria Especial da Mulher 2004 março; 1:130-47.

2. Farah M F S. Gênero e políticas Públicas. Rev Estud Fem 2004 janeiro; 12(1):71-4.

3. Coletivo Feminista Sexualidade e Saúde; Universidade de Säo Paulo, Faculdade de Medicina, Departamento de Medicina Preventiva, Centro de Saúde-Escola Prof. Samuel Barnsley Pessoa. Mulheres em situação de violência: guia de serviços. São Paulo: Coletivo Feminista Sexualidade e Saúde; 2002. $128 \mathrm{p}$.

4. Fontana M, Santos SF. Violência contra a mulher. In: Rede Nacional Feminista de Saúde e Direitos Reprodutivos, organizador. Saúde da mulher e direitos reprodutivos: dossiês. São Paulo: Rede Nacional Feminista de Saúde e Direitos Reprodutivos; 2001.

5. Schraiber LB, d'Oliveira AFPL, França-Junior I, Pinho AA. Violência contra a mulher: estudo em uma unidade de atenção primária à saúde. Revista de Saúde Pública 2002 agosto 36(4):470-7.

6. Lei 11.340 (BR) de 7 de agosto de 2006. Cria mecanismos para coibir a violência doméstica e familiar contra a mulher, nos termos do $8^{\circ}$ do art. 226 da Constituição Federal. Diário Oficial da União [periódico da internet]. 8 ago 2006.[citado 20/04/2008] Disponível em: http://www.planalto.gov.br/ CCIVIL/_Ato2004-2006/2006/Lei/L11340.htm.

7. Casique LC, Furegato ARF. Violência contra mulheres: reflexões teóricas. Rev Latino-am Enfermagem 2006 novembro/dezembro; 14(6):950-6.

8. Fonseca RMGS. Mulher e Cidadania na Nova Ordem Social. Núcleo de Estudos da Mulher e Relações Sociais de Gênero (NEMGE), Escola de Enfermagem da Universidade de São Paulo. São Paulo (SP): NEMGE; 1996.

9. Silva J, Dalmaso ASW. Agente Comunitário de Saúde: o ser, o saber, o fazer. Rio de Janeiro (RJ): Fiocruz; 2002.

10. Ministério da Saúde (BR). Fundação Oswaldo Cruz. Saúde da Família: avaliação em dez grandes centros urbanos: síntese dos principais resultados. 2ed. Brasília: Editora do Ministério da Saúde; 2005
11. Franzoi NM. Concepções de profissionais de equipes de saúde da família sobre violência de gênero [dissertação de mestrado]. Escola de Enfermagem, Universidade de São Paulo; 2007.

12. Bourdieu $P$, organizador. A miséria do mundo. Petrópolis: Vozes; 1997.

13. Minayo MCS. O Desafio do conhecimento: pesquisa qualitativa em saúde. 8ed. São Paulo: Hucitec; 2004.

14. Conselho Nacional de Saúde (BR). Comissão Nacional de Ética em Pesquisa - CONEP. Resolução No 196/96. Dispõe sobre Diretrizes e Normas Regulamentadoras de Pesquisas envolvendo Seres Humanos. Governo Federal - Brasília (DF): Conselho Nacional de Saúde; 1996.

15. Focault M. Microfísica do poder. São Paulo: Paz e Terra; 1997.

16. Oliveira CC, Fonseca RMGS. Práticas dos Profissionais das equipes de Família voltadas para as mulheres em situação de violência sexual. Rev Esc EnfermUSP 2007; 41(4):60713.

17. Guedes RN, Silva, ATMC, Coelho EAC. Vida de mulher e saúde: problematizando a realidade com os profissionais do cuidado. Rev online Brazilian Journal of Nursing. 2007 agosto; 6(2). Avaliable in: http://www.uff.br/objnursing/index.php/ nursing/article/view/j.1676-4285.2007.712/0

18. Meneghel $S$, Iñiguez L. Impacto de grupos de mulheres em situação de vulnerabilidade de gênero. Cadernos de Saúde Pública 2003 julho 19(4):109-18.

19. Diniz NMF, Almeida LCG, RBCS, Macêdo VG. Mulheres vítimas de violência sexual: adesão à quimioprofilaxia do HIV. Rev Latino-am Enfermagem. 2007 Fev; 15(1):7-12.

20. Vianna LAC, Bomfim GFT, Chicone G. Auto-estima de mulheres que sofreram violência. Rev Latino-am Enfermagem. 2006 Out; 14(5):695-701.

21. Roldán MCB, Galera SAF. Percepção do papel materno de mulheres que vivem em um contexto de drogas e violência. Rev Latino-am Enfermagem 2005 Dez; 13(spe2):1118-26. 22. David DMSL, Caufield C. Mudando o foco: um estudo exploratório sobre uso de drogas e violência no trabalho entre mulheres das classes populares da cidade do Rio de Janeiro, Brasil. Rev Latino-am Enfermagem. 2005 Dez; 13(spe2): 1148-54. 